\title{
Detrital K-Feldspar geochronology by collision cell MC-ICPMS/MS
}

\author{
D.G. BEVAN ${ }^{1 *}$, C.D. COATH ${ }^{1}$, J. LEWIS ${ }^{1}$, J.SCHWIETERS ${ }^{2}$, \\ N.S.LLOYD ${ }^{2}$, G.CRAIG $^{2}$, T. ELLIOTT ${ }^{1}$ \\ ${ }^{1}$ School of Earth Science, University of Bristol, Bristol, BS8 \\ 1RJ, UK (* correspondence: dan.bevan@bristol.ac.uk) \\ ${ }^{2}$ Thermo Fisher Scientific Bremen GmbH, Hanna-Kunath \\ Strasse 11, 28199 Bremen, Germany
}

Detrital alkali feldspars offer huge potential to investigate the evolution of the continental crust. Representing a major component of the crust that records an integrated prior history in readily measured initial $\mathrm{Pb}$ isotopic composition [e.g. 1], detrital K-feldspar offers valuable, complementary perspective to well-established zircon approaches. The impediment to realising this promise is being able to date single crystals with the efficiency of modern zircon geochronology. Our development of in situ $\mathrm{Rb}-\mathrm{Sr}$ dating by collision cell MC-ICPMS/MS removes this obstacle [2].

We use $\mathrm{SF}_{6}$ as a reaction gas to ensure chemical resolution of $\mathrm{Rb}$ and $\mathrm{Sr}$ during analysis [3]. The in situ analysis requires the use of a mass filter, prior to the collision cell, to significantly reduce the vareity and abundance of unwanted isobaric interferences.

Our use of collision cell MC-ICPMS/MS technology enables the dating of single K-feldspar grains in situ, with age resolutions as low as $1 \%$. We demonstrate using a $\mathrm{K}$-feldspar, from the Shap Granite, the ability to produce internal isochrons from single grains that are within uncertainty of the $\mathrm{Rb}$-Sr age and ${ }^{87} \mathrm{Sr} /{ }^{86} \mathrm{Sr}_{i}$ determined for the intrusion. This in situ $\mathrm{Rb}$-Sr dating of single $\mathrm{K}$-feldspar can be achieved, despite a relatively low intra-grain range in $\mathrm{Rb} / \mathrm{Sr}$, due to the high precision measurement of ${ }^{87} \mathrm{Sr} /{ }^{86} \mathrm{Sr}$ achievable with MCICPMS. Here we also exhibit the first application of this approach on detrital K-feldspars from the $\sim 1 \mathrm{Ga}$ arkosic sandstone from the Applecross Formation. The K-feldspar grains within the sandstone reveal a broad age spectrum with multiple age peaks. These peaks range from $1.1 \mathrm{Ga}$, associated with Grenvillian magmatism, to $2.3 \mathrm{Ga}$, which are interpreted as being derived from the underlying Lewisian Gneiss. This proof of concept for single grain in situ $\mathrm{Rb}-\mathrm{Sr}$ dating of $\mathrm{K}$ feldspar provides a powerful new tool for detrital geochronology.

[1] Tyrrell et al. (2006) Journal of Sedimentary Research, 76, 324-345

[2] Bevan et al. (2019) AGU Fall Meeting 2019. AGU.

[3]Cheng et al. (2008) Analytica chimica acta, 627 148-153 